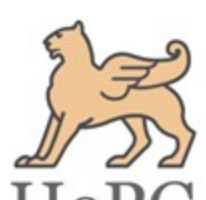

\title{
The moss Cyathophorum hookerianum (Griff.) Mitt. - new to Peninsular India from the Eastern Ghats
}

\author{
"A E D Daniels, P Monisha, M M Preetha, V Asha, P M Biju \\ Bryology Laboratory, Department of Botany \& Research Centre, Scott Christian College (Autonomous), Nagercoil 629003, India \\ (Affiliated to Manonmaniam Sundaranar University, Tirunelveli)
}

\section{Article history}

Received: 23 May 2018

Accepted: 23 July 2018

Published: 30 July 2018

\section{Editor}

Afroz Alam, Banasthali

University, Rajasthan, India

\section{Publisher}

Horizon e-Publishing Group

\author{
*Correspondence \\ A E D Daniels \\ \dulipdaniels@yahoo.co.uk
}

\begin{abstract}
Surveys carried out in the Kolli Hills of Eastern Ghats led to the discovery of Cyathophorum hookerianum (Griff.) Mitt. which is new to Peninsular India. On the other hand, the genus Cyathophorum P. Beauv. is new to the moss flora of the Eastern Ghats. A detailed description with illustrations and microphotographs are provided.
\end{abstract}

\author{
Keywords \\ Cyathophorum hookerianum; Eastern Ghats; Kolli Hills; Peninsular India
}

\section{Citation}

Daniels A E D, Monisha P, Preetha M M, Asha V, Biju P M. The moss Cyathophorum hookerianum (Griff.) Mitt. - new to Peninsular India from the Eastern Ghats. Plant Science Today 2018;5(3):128-130. https://dx.doi.org/10.14719/pst.2018.5.3.400

Copyright: (c) Daniels et al (2018). This is an open-access article distributed under the terms of the Creative Commons Attribution License, which permits unrestricted use, distribution, and reproduction in any medium, provided the original author and source are credited (https://creativecommons.org/licenses/by/4.0/).

\section{Introduction}

Kruijer [1] revised family Hypopterygiaceae of the World based on a series of phylogenetic analyses and merged genus Cyathophorella (Broth.) M. Fleisch. with that of Cyathophorum P. Beauv. which resulted in the transfer of a host of species under the latter with only 7 valid species for the world. Earlier, 6 species of Cyathophorum were recognized in India under the genus Cyathophorella [2]. Kruijer [1] reduced Cyathophorella anisodon Dixon \& Herzog, C. burkillii (Dixon) Broth., C. hookeriana (Griff.) M. Fleisch. and C. intermedia (Mitt.) Broth. to synonyms under Cyathophorum hookerianum (Griff.) Mitt. and Cyathophorella tonkinensis (Broth. \& Paris) Broth. to a synonym of Cyathophorum adiantum (Griff.) Mitt. Thus, only 2 species of Cyathophorum are currently known to occur in India of which Cyathophorum adiantum has been reported from the Western Ghats [3,4]. Hence, the present discovery of $C$. hookerianum in Kolli Hills of Eastern Ghats is an addition to the moss flora of Peninsular India and on the other hand genus Cyathophorum is new to the moss flora of the Eastern Ghats [5,6,7]. A detailed description with illustrations and microphotographs is provided.

\section{Key to the Indigens}

1a. Lateral leaves ovate to ovate-lanceolate, weakly bordered, spinose at margin above, faintly bordered or not, twisted at apex C. hookerianum

b. Lateral leaves oblong-ovate, serrate-spinose at apical margin, distinctly bordered, not twisted at apex C. adiantum 


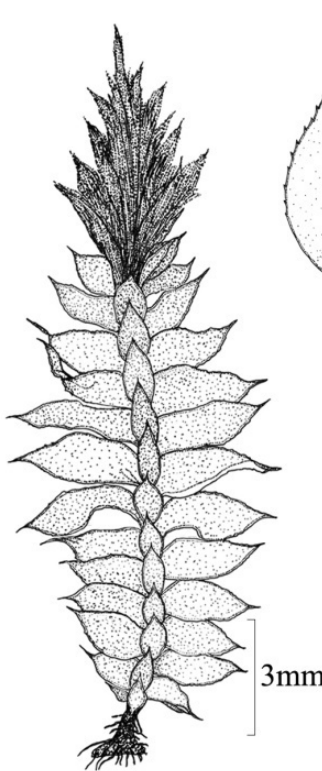

A

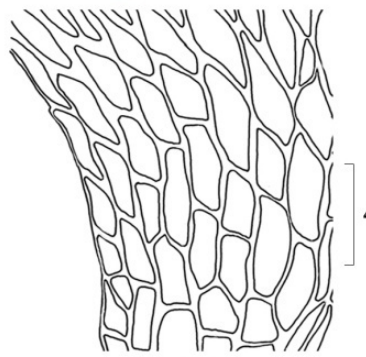

H

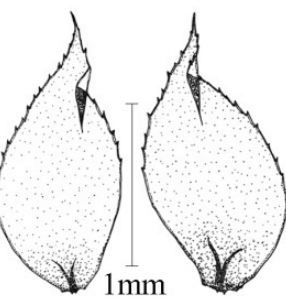

B

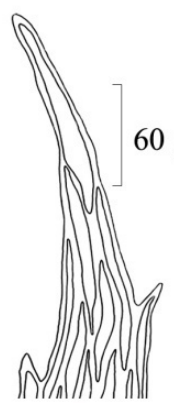

$\mathbf{E}$

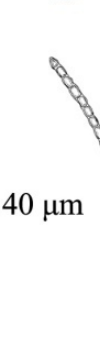

E

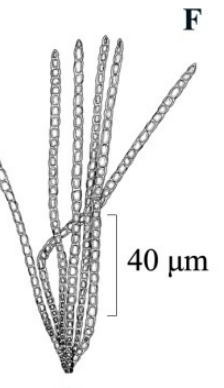

I

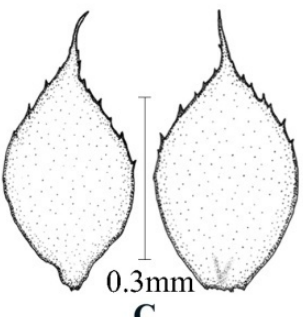

C

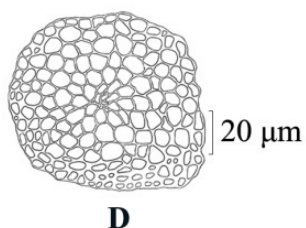

D

Fig 1. (A-K ). Cyathophorum hookerianum (Griff.) Mitt.

A. Plant B. Lateral leaves C. Ventral leaves D. Cross section of stem E. Apical leaf cells F. Marginal leaf cells G. Median leaf cells H. Basal leaf cells I. Gemmae J. Gemmae with apical cells K. Gemmaphore (P.M. Biju 1510 p.p.)

Cyathophorum hookerianum (Griff.) Mitt., J. Proc. Linn. Soc., Bot. 1(Suppl.): 147. 1859; Kruijer, Blumea (Suppl.) 13: 337. 2002. Neckera hookeriana Griff., Not. Pl. Asiat. 2: 464.1849 \& Icon. Pl. Asiat. 2: 84, f. 2-2a. 1849. - Type: India, Assam, Griffith s.n. (NY - lectotype vide Kruijer, l.c.). (Figs. 1 \& 2)

Plants loosely caespitose, pale green to green. Primary stems rhizomatous, tomentose; secondary stems $2-4 \mathrm{~cm}$ tall, $0.28-0.30 \times 0.22-0.23$ $\mathrm{mm}$ in cross section, ovate, with a faint central strand; cortex 2- or 3-layered; cells 12-32 × 11-24 $\mathrm{mm}$, rounded-quadrate, thick-walled; medullary cells 16-36 × 14-28 mm, rounded-hexagonal, thinwalled. Lateral leaves contiguous, wide-spreading, $3.5-4.5 \times 2.0-2.7 \mathrm{~mm}$, ovate to ovate-lanceolate, slightly asymmetric, weakly bordered, spinose at margin above, acuminate and twisted at apex; axillary hair absent; apical leaf cells 24-80 × 8-12 $\mu \mathrm{m}$, rhomboid; median leaf cells 24-51 × 8-16 $\mu \mathrm{m}$, elongate-hexagonal, pitted; basal leaf cells 20-56 $\times$ 16-20 $\mu \mathrm{m}$, elongate-hexagonal, pitted; costa short, forked. Ventral leaves 1-rowed, symmetric, 1.0-1.5 $\times 0.5-1.0 \mathrm{~mm}$, ovate-acuminate, weakly bordered, ecostate or faintly costate, forked. Gemmae clustered at distal half of stem, filamentous, to 30celled, pale brown. Sporophyte not seen.
Habitat: Corticolous on Diospyros melanoxylon Roxb. (Ebenaceae), in degraded evergreen forests.

Distr.: Bhutan, Cambodia, China, Indonesia, Japan, Laos, Malaysia, Myanmar, Nepal, the Philippines, Taiwan, Thailand, Vietnam and India: Western Himalaya (Uttar Pradesh), E. Himalaya (Arunachal Pradesh, Sikkim and W. Bengal), NE. India (Meghalaya) [1,2] and Eastern Ghats of Tamil Nadu (Namakkal).

Specimens examined: Eastern Ghats: Tamil Nadu, Namakkal Dist., Kolli Hills, Perumakka Shola, ca 1240 m, 21.01.2016, P.M. Biju 1510 p.p. (SCCN).

\section{Discussion}

Kruijer [1], recognizes two ecological variants; one prefers a warm-temperate habitat and the other a more tropical, humid habitat in riparian and monsoon forests. The tropical variant is usually more robust, with straight and semi-erect to erect secondary stems. The leaf border is faint to distinct, usually continuous reaching the acumen. The material to hand agrees well to all these features and hence a tropical variant. The occurrence of this species indicates that the 


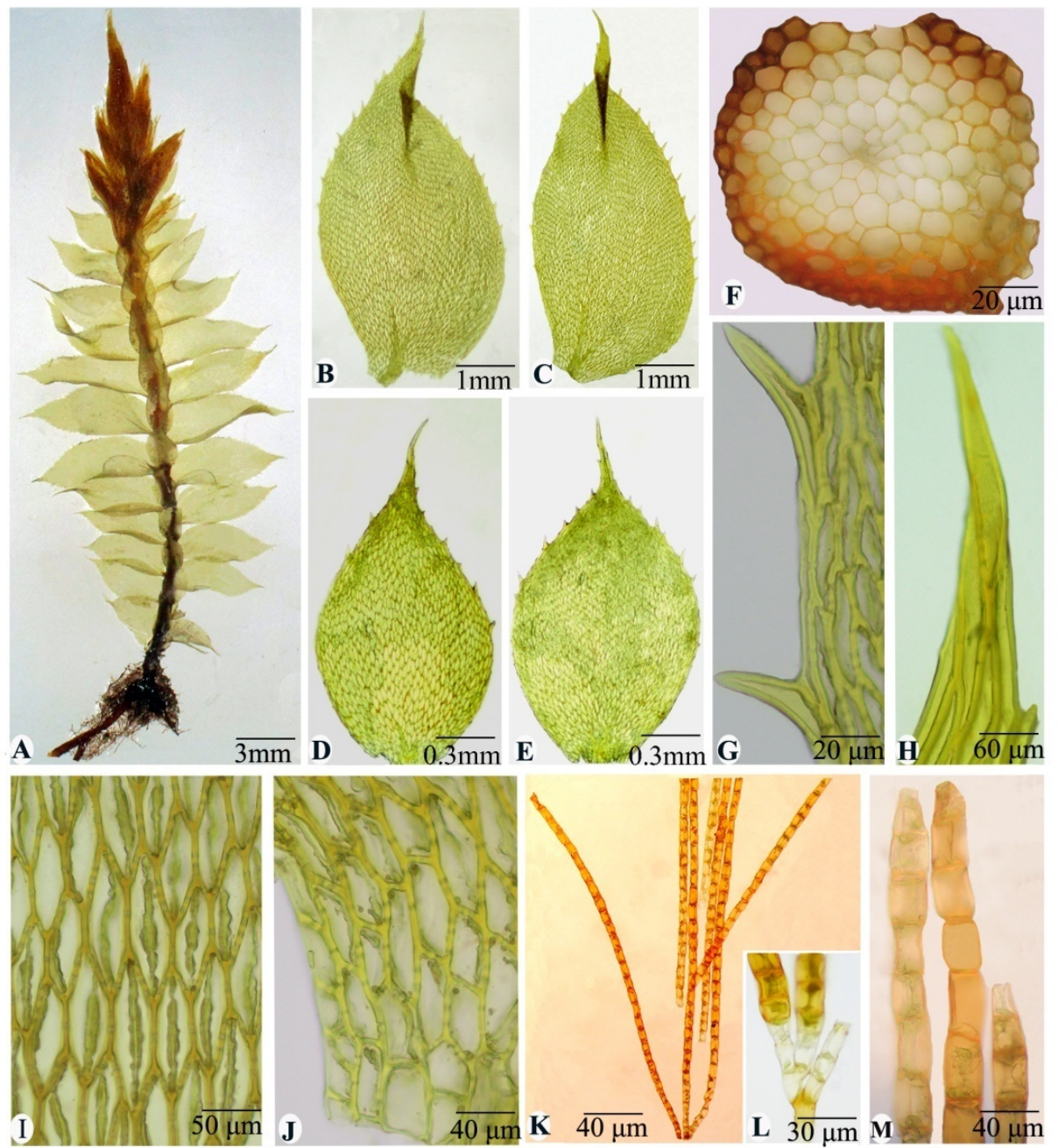

Fig. 2 (A-M ). Cyathophorum hookerianum (Griff.) Mitt.

A. Plant B\&C. Lateral leaves D\&E. Ventral leaves F. Cross section of stem G. Marginal leaf cells H. Apical leaf cells I. Median leaf cells J. Basal leaf cells K. Gemmae L. Gemmaphore M. Gemmae with apical cells (P.M. Biju 1510 p.p.)

evergreen forests occurring in Kolli Hills, though degraded and fragmented, are still moist and humid, and are potential habitats for moisture loving bryophyte species such as Cyathophorum hookerianum thereby re-iterating the need for their conservation.

\section{Authors' contribution}

AEDD - Collection, determination and preparation of the MS; PM - Dissection and help in determination; MMP Dissection and preparation of colour plate; VA Dissection and preparation of figures; PMB - Collection.

\section{Acknowledgements}

The authors thank the Tamil Nadu State Forest Department for permission to explore the study area and help in the field, the Ministry of Environment, Forests \& Climate Change, Govt. of India, New Delhi, for financial assistance, and the Principal, Scott Christian College, for facilities.

\section{Conflict of interest}

The authors declare that they have no competing interests.

\section{References}

1 Kruijer H. Hypopterygiaceae of the world. Blumea (Suppl.) 2002; 13: 1-388.

2 Lal J. A checklist of Indian mosses. Dehra Dun: Bishen Singh Mahendra Pal Singh; 2005. P. 1-164.

3 Nair MC., Rajesh KP., Madhusoodanan PV. Checklist of the bryophytes of Kerala, India. Trop. Bryol. Res. Rep. 2008; 7: 1-24.

4 Schwarz U. An updated checklist of bryophytes of Karnataka. Arch. Bryol. 2013; 181: 1-42.

5 Kumar GV, Krishnamurthy KV. Moss flora of Shervaroy Hills of Eastern Ghats (South India). In: Nath V, Asthana AK, Editors. Current Trends in Bryology. Dehra Dun: Bishen Singh Mahendra Pal Singh; 2007. p. 227-243.

6 Palani R, Sathish SS, Thamizharasi T, Vijayakanth P. Checklist of Mosses (Bryophyta) of Bodamalai Hills in Eastern Ghats, Tamil Nadu. Pl. Sci. Today 2017; 4: 4954. https://doi.org/10.14719/pst.2017.4.1.278

7 Sathish SS, Thamizharasi T, Palani R, Vijayakanth $\mathrm{P}$, Vimala A. Checklist of mosses Bryopsida) of the Kalrayan Hills in the Eastern Ghats of Tamil Nadu, India. Eng. Biosci. 2014; 2: 28-33.

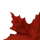

